\title{
Depiction of Pandemic in Indonesia Local Election 2020 Political Advertising
}

\author{
Robby Firmansyah ${ }^{1}$, Martinus Dwi Marianto ${ }^{2}$ \\ ${ }^{1}$ Universitas Muhammadiyah Bengkulu \\ ${ }^{1}$ Doctoral Student of Graduate School, Indonesia Institute of the Art Yogyakarta \\ ${ }^{2}$ Indonesia Institute of the Art Yogyakarta \\ E-mail: robbyfirmansyahmuish@gmail.com
}

\begin{abstract}
In the last quartal of 2020, during the Covid-19 pandemic, local elections were held in various cities and provinces in Indonesia. As a result of the public awareness of the pandemic situation and the urgent need for solutions to its implications, the Covid-19 pandemic became a suitable theme to be addressed on election campaign media. This paper aims to generate various patterns on how candidates utilized Covid-19 pandemic imageries in their political advertising to establish their personal brand. Thematic analysis was employed to identify the various patterns on how candidates utilized Covid-19 pandemic imageries in their political advertising. 329 Covid-19 related political advertisements from various candidates were reviewed to generate patterns on candidates' personal brand establishment. The study found that promoting Covid-19 safety protocols, candidates' strategies, and appreciation toward frontline workers became three major themes in depicting the pandemic in Indonesia local elections 2020 political advertising. Covid-19 pandemic-related imageries are employed to perform their informative functions and as a context in which political advertising can perform its persuasive function.
\end{abstract}

Keywords: pandemic, politics, advertising, personal brand

Penggambaran Pandemik pada Iklan Politik Pemilihan Kepala Daerah 2020 di Indonesia

Abstrak

Pada akhir tahun 2020, di tengah merebaknya pandemi Covid-19, dilakukan pemilihan kepala daerah di berbagai kota dan provinsi di Indonesia. Sebagai hasil dari kesadaran masyarakat terhadap situasi pandemi dan pentingnya solusi-solusi dalam menghadapi implikasinya, pandemi Covid-19 menjadi tema yang sesuai untuk dibahas pada media kampanye. Karya tulis ini ditujukan untuk membentuk tema-tema dari penggambaran pandemi Covid-19 yang digunakan oleh kandidat pemilihan pada iklan kampanye dalam membentuk citra dirinya. Analisis tematis digunakan untuk membentuk berbagai pola mengenai penggambaran pandemi Covid-19 yang digunakan oleh para kandidat pada iklan kampanyenya. 329 iklan kampanye terkait pandemi Covid-19 dari berbagai kandidat dikaji untuk menghasilkan pola-pola pembentukan citra diri kandidat pemilihan. Kajian ini membentuk tiga tema dari penggambaran pandemi pada iklan kampanye politik pemilihan kepala daerah 2020 yang berupa: mempromosikan protokol keamanan Covid-19, strategi kandidat, dan apresiasi terhadap pekerja garda depan Covid-19. Penggambaran terkait Covid-19 pada iklan kampanye tidak hanya digunakan untuk menjalankan fungsi informatif iklan kampanye, tetapi juga untuk menjalankan fungsi persuasifnya.

Kata kunci: pandemi, politik, iklan, citra diri 


\section{INTRODUCTION}

On December $9^{\text {th, }} 2020$, during the Covid-19 pandemic, local elections were held in various cities and provinces in Indonesia. As part of Indonesia's democratic system, elections allow the public to practice their political rights directly and determine the leader of their region for the next five years. As ruled in its election system, candidates had been given 71 days from September 26th, 2020, to December 5th, 2020, to promote themselves and persuade the public to entrust their vote to a particular candidate through various means.

Continuous escalation of the Covid-19 pandemic in Indonesia had affected the 2020 political campaign process, which is distinct from any previous political campaign activities. Considering various implications produced by the Covid-19 pandemic situation, various political campaign activities that gather a mass of people and involve direct communication between candidates and voters, which used to be the norm of Indonesia's political campaign activities in pre-pandemic, were strictly permitted in the 2020 political campaign. Furthermore, with the government's sanction on the limitation of public mobility during the pandemic where each citizen is advised to limit their outdoor activities, outdoor advertising seems to be less effective to employed during the pandemic than what it used to be. The devastating spread of the pandemic forced each candidate to formulate alternate political campaign approaches that differed from typical campaign activities usually held in previous periods.

As a result of public mobility limitation and stay-at-home order during the Covid-19 pandemic, numbers of candidates shift from conventional outdoor media to a more personalized media - communication media that enable the candidate to convey information and idea to the public through communication devices that are used and own by the public individually. Social media can establish communication between candidates and the public with slight limitation in terms of time and space. Inevitably the usage of social media as a communication channel by the candidates had increased during the pandemic. Specifically, Instagram became a social media platform that election candidates frequently used as campaign media during the pandemic. The prominence of visual elements inherent in Instagram as candidates had utilized communication media as a substitution for conventional outdoor media to establish communication to their potential voters. The limitation of time and space had become a significant problem in conducting political campaigns during the pandemic.

Regarding its implication, the Covid-19 pandemic affected how candidates conduct their political campaigns and the content of campaign media itself. As a result of public awareness towards the Covid-19 pandemic situation formed by various information directly or indirectly retrieved by the public, Covid-19 
pandemic discourse became a relevant topic to presented by candidates in their political campaign advertising. Furthermore, the importance and urgency of means and solutions on dealing with pandemic situations became an opportunity for the candidates to exhibit their point of view, plan of action, and leadership quality to cope with the dire situation of the Covid-19 pandemic to the public. Visual elements play significant functions in advertising which could alter the relationship between audiences and the candidates (Grabe \& Bucy, 2011), impression formation and persuasion (Nagel et al., 2012), drawing an increasing audiences' attention (Fahmy et al., 2014). Throughout campaigning during the pandemic, candidates portrayed their point of view and reaction toward Covid-19 by utilizing visual signs within political campaign advertising posted on their Instagram account. Pandemic discourse visualized in political campaign advertising served as information that candidates should convey to the public and is also employed to influence how the public perceives and establishes candidates' brands. Therefore, the establishment of a candidate's personal brand during the campaign during pandemic not only could be achieved by representing general idea about him/herself (i.e., value, personality, expertise), but also can be established by specifically depicting candidate's point of view, ideas, and reactions toward the devastating Covid-19 pandemic in his/her political campaign media. This paper aims to discover various patterns on how candidates utilized Covid-19 pandemic imageries in their political advertising to establish their personal brand.

\section{MATERIAL AND METHOD}

329 political advertising posted by candidates to their Instagram account were reviewed to generate patterns on political advertising during the pandemic. Those 329 Covid-19 related political advertising were selected from thousands of political advertisings posted by candidates from various local elections. Each political advertising that was reviewed must include at least one Covid-19 related visual element. Therefore, the selection process excluded political advertising that did not include any Covid 19 pandemic-related visual imageries. Political advertising that is being reviewed must be posted during the political campaign period from September 26th, 2020, to December 8th, 2020. The researcher also put the intensity of Instagram usage as campaign media by each candidate as a consideration during the material selection process. Covid-19 pandemic-related visual elements consist of any visual element within the political advertising which conveyed any explicit or implicit message that can be related to Covid-19 pandemic discourse such as the depiction of a mask, pandemic protocol, or any activities that can be associated to the public health during the pandemic. 
Thematic analysis was employed to identify various themes of Covid-19 related imageries from political advertising used by candidates to build their personal brand in public eyes. Thematic analysis is a method for identifying, analyzing, and reporting patterns (themes) within data (Braun \& Clarke, 2006). Concerning image and social media research, thematic analysis was employed to identify patterns of social media users on posting and liking image behaviour (Braun \& Clarke, 2006). Concerning image and social media research, thematic analysis was employed to identify patterns of social media users on posting and liking image behaviour (Lowe-Calverley \& Grieve, 2018), and was utilized to identify the themes and underlying meanings of \#fitspiration posts in social media (Deighton-Smith \& Bell, 2018). In this paper, thematic analysis was utilized primarily to assess visual elements in political advertising to generate patterns on the depiction of Covid-19 pandemic imageries that candidates employed to establish their brand. Although the verbal aspect was not the primary focus in this paper, the verbal aspect in political advertising was utilized to provide a more fitting underlying meaning of visual elements assessed.

The inquiry process in this paper will follow the guide in conducting thematic analysis presented by Braun and Clarke (2006). The first phase involves the process where the researcher familiarizes himself with the data. The second phase, based on reading from the previous phase, will generate initial codes upon Covid-19 related visual elements in political advertising reviewed. Next, codes produced were then grouped into several initial themes based on the correlation between codes. In the fourth phase, initial themes then undergo reviewing processes conducted by reviewing codes in each initial theme to determine whether those codes established a coherent theme and the individual theme concerning the entire data set. As mentioned by Braun and Clarke (2006), upon completing the fourth phase, the researcher will obtain sufficient understanding to identify different themes, how each theme correlates to each other, and the overall narrative of the data. The fifth phase involves defining and naming each theme in which the researcher must identify the essence of each theme and the story narrated by each theme.

\section{RESULTS}

Close reading on the material produced three themes on Covid-19 related imageries that candidates used in their political advertising to establish their brand through the political campaign media amid the pandemic. 


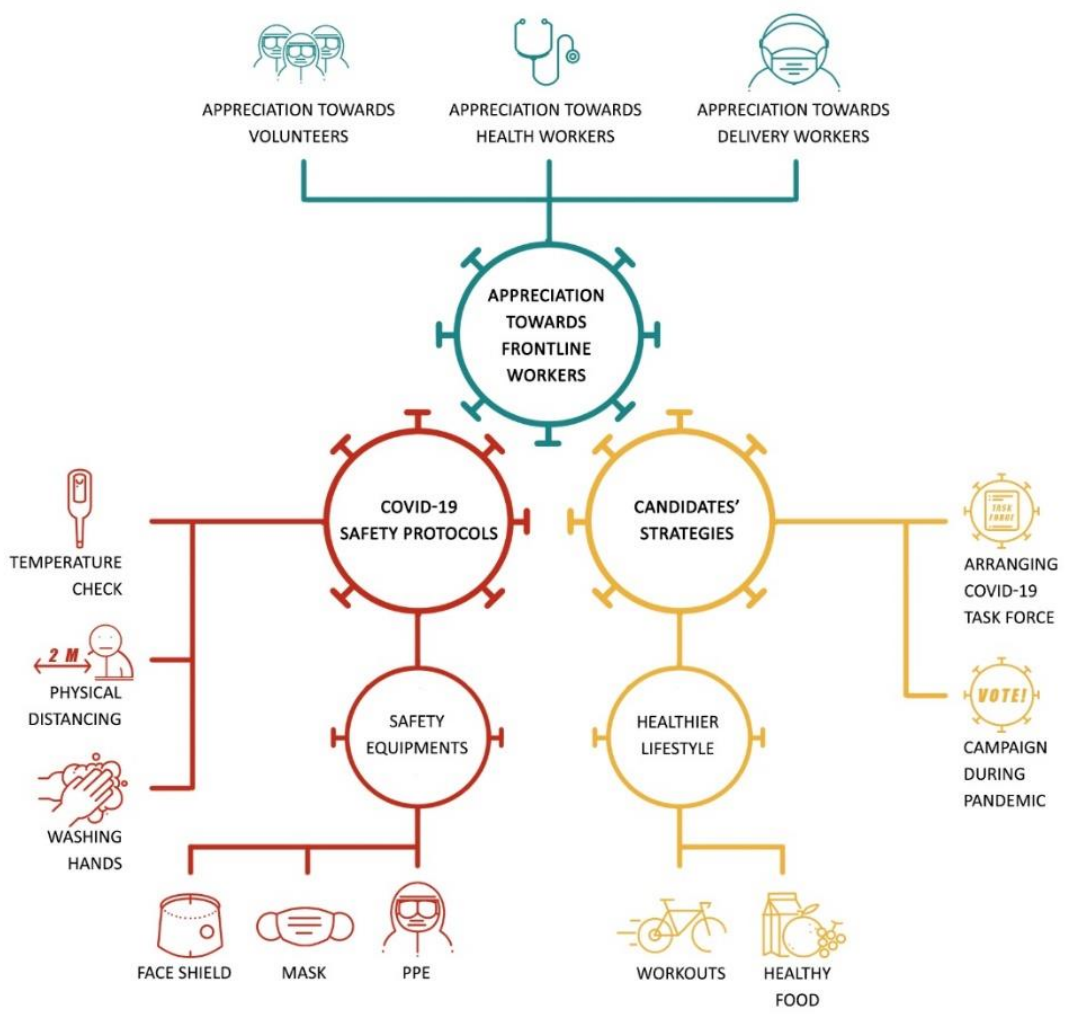

Figure 1. Themes, sub-themes, and codes of Covid-19 related imageries in Indonesia local election 2020 political advertising

Source: Author, 2021

\section{Promoting Covid-19 Safety Protocols}

Campaigning during the Covid-19 pandemic resulted in the importance of inclusion of the event that was directly experienced by the public. Promoting Covid19 safety protocols in candidate's election campaign media not only showing that the candidate supporting the preventive measures advised by the government on dealing with Covid-19 pandemic, but also exhibiting the point of view on the existence of Covid-19 pandemic where public and candidate should take part to protect him/herself and everyone around him.

\subsection{Mask}

One of the most frequent Covid-19 related visual elements used by candidates in their campaign media is the depiction of face masks. Face masks have become one of the items that highly correlate with the Covid-19 pandemic. It is currently acknowledged that the Covid-19 virus can spread directly from human to human through droplets from the nose and mouth and indirect contact with a contaminated object and airborne contagion (Lotfi et al., 2020; Shereen et al., 2020; $W H O, 2020)$. The instruction to wear at least a mask while doing outdoor activity ruled by the government as a preventive measure to cope with the spread of the 
Covid-19 pandemic resulted in wearing a mask as a new norm in daily life during the pandemic. Therefore, depicting masks within election campaign media became a relatively more straightforward attempt to associate candidates to the Covid-19 pandemic and the public. Some campaign media depicted the candidate or others wearing a mask, candidates helping others to wear a mask, candidates giving a mask to other people, or only portraying a mask in election candidate's campaign media. It needs to be noted that, although face mask became one of the most visible Covid19 related visual imageries in election campaign media, however, there are campaign media that depicting election candidates did not wear it properly. Some campaign media depict candidates carrying the mask in their hand while doing campaign activity in the public and wearing a mask under their chin that does not cover their mouth and nose.

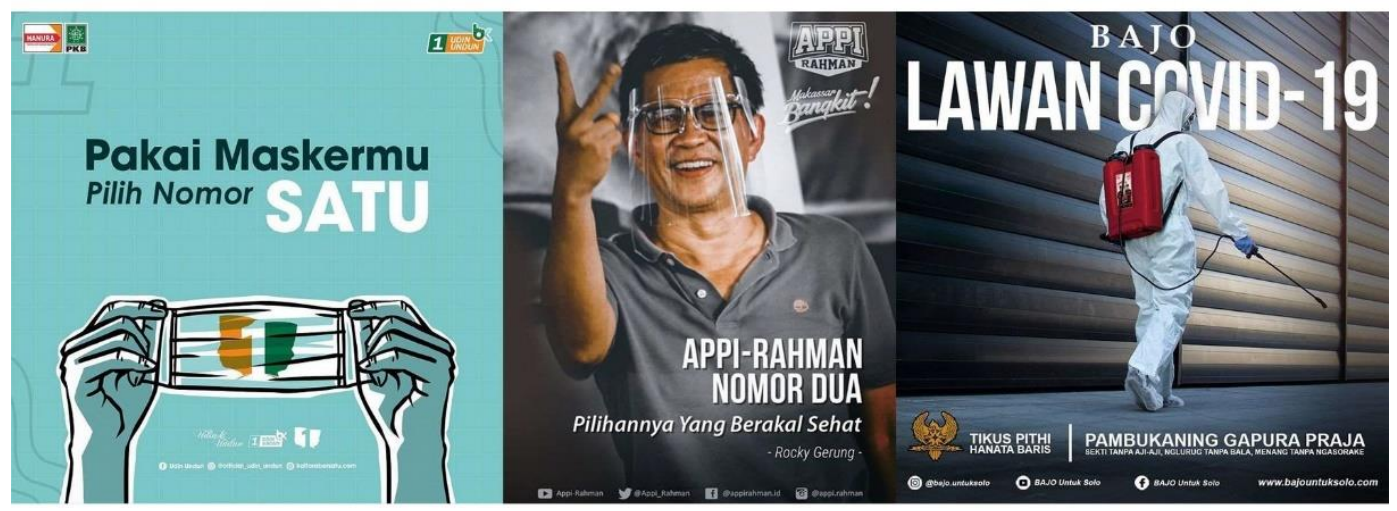

Figure 2. Depiction of Covid-19 safety equipment sub-themes: mask, face shield, and PPE Sources: www.instagram.com/official_udin_undun, 2020; www.instagram.com/appi_mika, 2020; www.instagram.com/bajo.untuksolo, 2020

\subsection{Face shield}

Even though not as frequently depicted as masks in election campaign media, some candidates depict themselves or others wearing face shields along with face masks in their campaign media. Popular media, television especially, play a significant role in establishing the relation between face shield and Covid-19. The participants in various T.V. programs were shown to wear a face shield when broadcasting during the pandemic.

\subsection{Personal Protective Equipment (PPE)}

Personal Protective Equipment (PPE), along with face masks, before pandemics, was commonly associated with health workers and patients in the hospital. During the pandemic, PPE symbolized the need to protect oneself from the virus and how easy for the virus to infect and spread from one person to another. Compared to other safety equipment, the depiction of PPE in election campaign media can create a more severe and dark note toward the pandemic. Depicting health workers or volunteers wearing PPE in election campaign media exhibited the 
candidate's point of view on the problematic situation and devastating implication caused by the Covid-19 pandemic.

\subsection{Physical distancing}

Apart from safety equipment sub-theme as Covid-19 related visual code in election campaign media, the theme of promoting Covid-19 safety protocols also included advising physical distancing protocol. Physical distancing protocol in election campaign media was shown by advising people to stand apart and depicting campaign activity where the participants stand or sit apart from each other with measured distance. Along with wearing a mask, during the pandemic, the public is advised to distance him/herself from other people when they are in the public space to minimize the risk of Covid-19 virus transmission (Pratomo, 2020; Dewi \& Probandari, 2021). Similar to the case of wearing a mask, reading on the material found that there are candidates that depicted themselves in their campaign media breaking physical distancing protocol especially when they are conducting their campaign activity in the public.

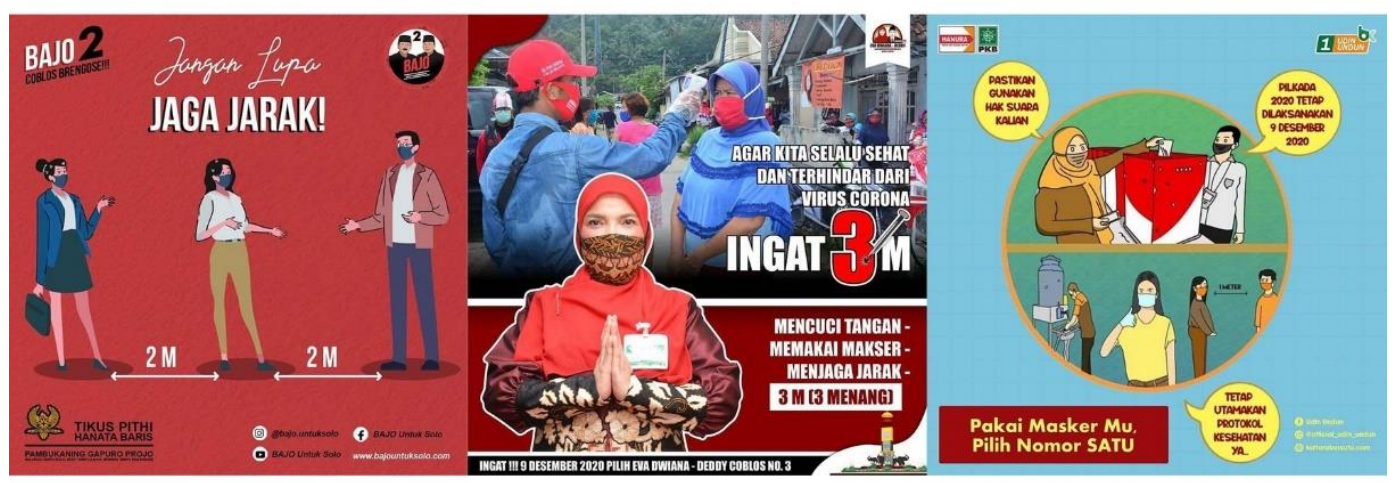

Figure 3. Depiction of physical distancing, temperature check, and washing hands visual codes Sources: www.instagram.com/bajo.untuksolo, 2020; https://www.instagram.com/eva_dwiana, 2020; www.instagram.com/official_udin_undun, 2020

\subsection{Washing hands}

Although quite scarce in terms of exposure, some election campaign media employed imagery that suggests or reminds people to wash their hands as a preventive measure toward the spread of the Covid-19 pandemic. These imageries convey through visual icons that portray the action of washing hands.

\subsection{Temperature check}

Similar to the depiction of washing hands, only a few election campaign media portray the action of measuring a person's body temperature when holding campaign activity as a preventive measure. The association between measuring body temperature and the Covid-19 pandemic could be established by the current 
regulation needed by someone to enter public buildings such as markets, restaurants, governmental buildings, hospitals, universities, etc.

\section{Candidates' Strategies Toward Pandemic}

Considering that the candidates must exhibit their expertise to the public as an attempt to convince the public that they have the leadership and ability needed to run the government, campaign media become a channel that provides the opportunity for the candidate to exhibit the vision and plan of action to tackle various challenges and public concerns. Implications brought by the Covid-19 pandemic upon society become one of many challenges that elected candidates to have to deal with. How candidates reacted to the Covid-19 pandemic became a theme generated from election campaign media exhibiting their ability to deal with challenging situations.

\subsection{Promoting workouts}

Maintaining health and immunity and implementing Covid-19 safety protocols have become one of the various ways to protect ourselves from the Covid19 virus. During the campaign period, some candidates exhibited their vision on dealing with pandemic situations by advising the public to do some workouts such as playing football, jogging, and cycling, which are pretty popular and accessible sports for the public. While football is one of the most popular sports in Indonesia even before the pandemic, cycling gains its popularity during the pandemic. Promoting exercising such as playing football, jogging, and cycling to the public showed how the candidate can provide another suggestion or plan to deal with the Covid-19 situation apart from the existing regulation, namely Covid-19 safety protocols.

\subsection{Promoting healthy food}

Within the sub-theme of promoting a healthier lifestyle and promoting workouts/exercise, some candidates also promote the consumption of healthier food to the public as a suggestion to maintain public health while dealing with the Covid19 situation. This visual code was depicted by including the sources of nutrients that can help the public maintain their health.

\subsection{Arranging Covid-19 taskforce}

To deal with the pandemic situation, some candidates organized their volunteers, or the Covid-19 task force. Some campaign media depicted a group of volunteers assembled by a candidate to help the public deal with the pandemic. Some candidates also portrayed the task forces that they assembled spraying disinfectant on citizen houses. Like promoting a healthier lifestyle, arranging Covid-19 volunteer or task force exhibited the candidate's strategy on dealing with 
Covid-19 pandemic that hopefully will be able to enhance public perception toward the candidate in terms of how the candidate deals with real-life challenges.

\subsection{Campaigning during pandemic}

Conducting a political campaign during the pandemic becomes a challenge in itself. Some candidates utilize visual elements to illustrate how they conducted their campaign activity during the pandemic to assure the public that they conducted their campaign activities appropriately considering situations caused by the Covid19 pandemic. This explanation becomes vital to answer the questions regarding the safety of campaign activity held by the candidate and whether candidates implement many things they suggested to the public. This explanation can be conveyed by depicting the candidate implementing Covid-19 safety protocols and conducting his campaign activity with a virtual meeting.

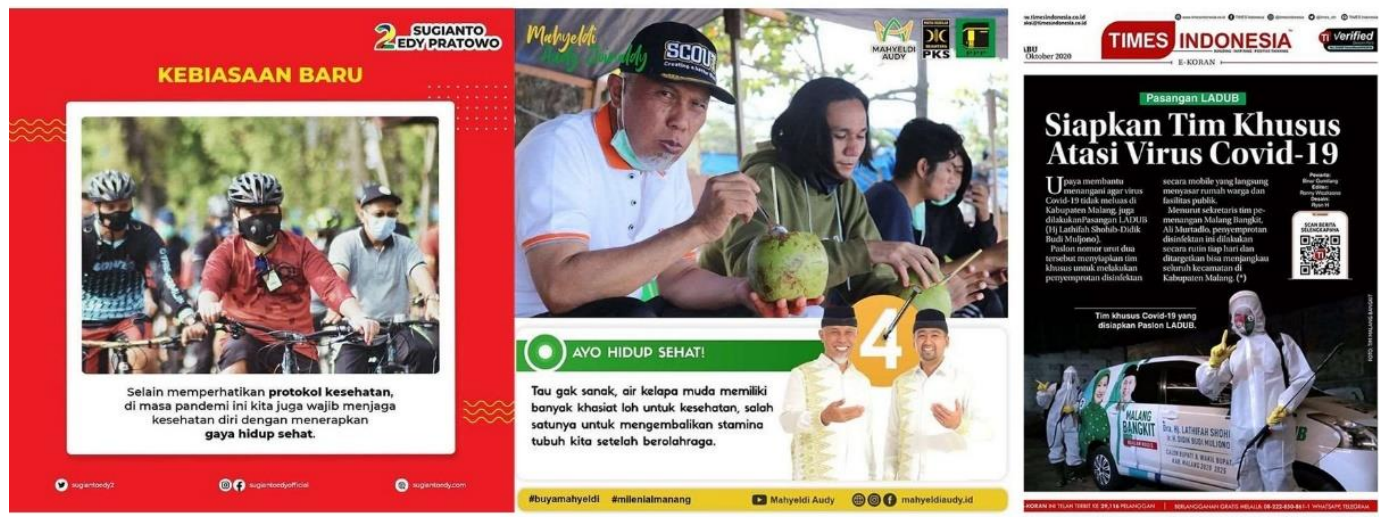

Figure 4. Depiction of promoting workouts, healthier food, and arranging Covid-19 taskforce visual codes

Sources: www.instagram.com/sugiantoedyofficial, 2020; www.instagram.com/mahyeldiaudy.id, 2020; www.instagram.com/ladubcenter, 2020

\section{Appreciation Toward Frontline Workers}

Another theme generated from Covid-19 related imageries in election campaign media is appreciation towards essential workers who play a significant role to help the public to deal with the Covid-19 situation.

3.1 Appreciation toward health workers

During the pandemic, health workers become the first group in the line to deal with the Covid-19 pandemic. Through their campaign media, election candidates exhibit their support toward the health workers and their pivotal roles in assisting the public to deal with the pandemic situation. Most of the campaign media that show candidates' appreciation toward health workers published around the National Health Day and National Doctor Day that happened within Indonesia's local election campaign period. 


\subsection{Appreciation toward volunteers}

As health workers, appreciation toward the Covid-19 volunteer could also establish an association between candidates and volunteers' positive attributes such as empathy and willingness to help other people.

\subsection{Appreciation toward delivery service workers}

During the pandemic, with the government suggesting that the public limit their outdoor activity and mobility, delivery service workers play a significant role to help the public fulfilling their daily necessities. Unlike health workers, especially doctors that can be categorized within the upper-class group in society in terms of their income, delivery service workers primarily consisted of the lower-class workers. Showing appreciation toward delivery service workers can convey the idea of the candidate's inclusiveness toward the lower-class group of society which is a big part of the society.

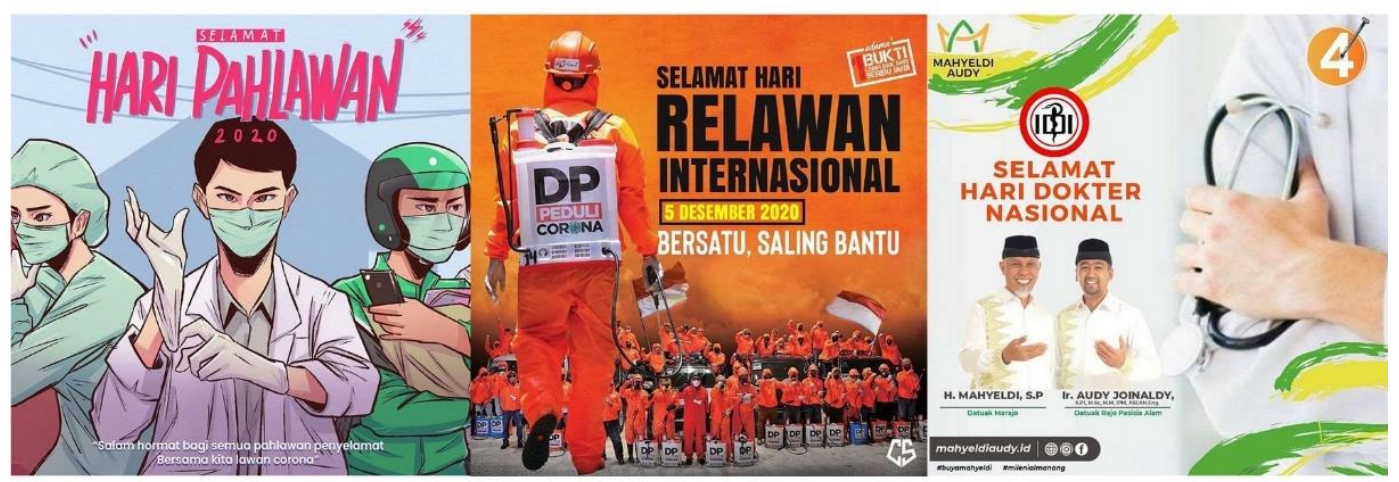

Figure 5. Depiction of appreciation towards frontline worker's theme Sources: www.instagram.com/gibran_rakabuming, 2020; www.instagram.com/dpramdhanpomanto, 2020; www.instagram.com/mahyeldiaudy.id, 2020

\section{DISCUSSION}

The Covid-19 pandemic-related imageries presented in Indonesia local election 2020 campaign media can be categorized into three themes: promoting Covid-19 safety protocols, candidate's strategies, and appreciation toward frontline workers. Looking into each theme closely, we will be able to see the function of each theme to enhance the candidate's brand and the overall narrative formed by the correlation between each theme as a unit.

Promoting Covid-19 safety protocols through visual elements in election campaign media can be seen as an attempt from the candidate to convey their point of view toward the Covid-19 pandemic situation and support Covid-19 pandemic regulations ruled by the Indonesian government. Russmann et al. (2019) characterized this message content as broadcasting-Instagram postings that 
convey stances, performances, opinions, and ideas to the followers. Advising other people to implement Covid-19 safety protocol by utilizing visual elements in campaign media will be able to form an association between candidate and the construct of universalism value-understanding, appreciation, tolerance, and protection for the welfare of all people, and the personality trait of friendliness concern and sensitive towards others and their needs (Caprara et al., 2006). It could be concluded that utilizing Covid-19 related visual elements to promote Covid-19 safety protocol served to inform and remind the public to implement safety protocols and could enhance the candidate's brand.

Regarding the candidate's strategy's theme, along with enhancing his universalism and friendliness in terms of personal value and personality trait respectively, showing his/her reaction apart from promoting Covid-19 safety protocols will exhibit the candidate's competency to deal with challenging situations. Expertise (Montoya \& Vandehey, 2009) or competency (Rampersad, 2008) is one of the aspects of personal brand establishment. Exhibiting the candidate's plan of action and reaction toward pandemic situations through campaign media can illustrate how the candidate deals with challenging situations. A glimpse of the candidate's capability to deal with a challenging situation will establish the public's expectations toward the candidate. Furthermore, suppose the plan of action provided by the candidate is perceived to be beneficial for the general public or segmentation of it. In that case, the candidate's brand will likely be perceived more positively by that segmentation of the public.

The theme of appreciation toward frontline workers can be seen as an attempt to exhibit inclusiveness. Inclusiveness in a sense that every part of the public plays a role to deal with the pandemic situation, and also the candidate as a part of those who took an action on dealing with pandemic situation for the better of the whole society. Hopefully, by reaching out to health workers, volunteers, and delivery service workers, we will be able to create a symbolic relation between candidates and those who play a pivotal role in public life during the pandemic. Reaching out to other parts of society, especially delivery service workers, will portray a populist narrative - the candidate as one with the people (Grabe \& Bucy, 2011). By conveying appreciation toward frontline workers, the candidate will be able to depict him/herself as part of the mass public and attempt to create a positive relationship with the public.

The depiction Covid-19 related imageries in election campaign media were able to convey the narrative in which portrayed the candidate's belief of the existence of the Covid-19 pandemic and its various threats and implications, and also portraying candidate's empathy toward public health and safety, which become of the biggest concern during the pandemic. Candidate's belief or value-what is considered as important and serve as guiding principle of life, and personality 
traits - the tendency of patterns of thought, feeling, and action to describe what people are like (Caprara \& Vecchione, 2017), become two important aspects on establishing his/her personal brand (Montoya \& Vandehey, 2009). Considering the similarity-attraction paradigm and voting as an expressive role for the voter, candidate personality (trait and personal value) can draw voters with a similar personality (Caprara et al., 2006). Regarding the candidate's empathic feeling toward public health, goodwill - to be recognized positively-becomes one criterion on the personal brand establishment (Rampersad, 2008). Exhibiting the gesture of caring and willingness to help will help the candidate establish a positive public image.

Santilli (1983) suggested that advertising performs two functions which are the informative and the persuasive function. However, Emamalizadeh (1985), commenting on Santilli's work, argued that advertising performs only one function: persuasion. Persuasion is defined by O'keefe (2016) as a successful intentional communication effort to influence others' mental state; or as a symbolic process where the communicators utilize a form of language to influence other people attitudes and behaviours (Perloff, 2017). It is important to note that the candidate does not only utilize Covid-19 related imageries within election campaign media to inform the public on how the public should react and how the candidate reacts to the Covid-19 pandemic situation but also serve as persuasive tools for the candidate as an attempt to draw voters' support to increase candidate's electability-utilizing Covid-19 discourse, along with many other discourses, as a context to exhibit candidate's value, goodwill, and inclusiveness through visual elements in election campaign media can also be seen as an attempt from the candidate to enhance their personal brand and to influence voter's decision-making process so that the voters' willing to give their vote on one particular candidate.

The study found some contradictions within the campaign media that, on the one hand, the candidate was advised to implement the Covid-19 safety protocol. On the other hand, their campaign media depicting themselves did not implement their advice or did not do it properly, especially wearing a mask and social distancing protocols. The contradiction depicted by candidates' campaign media could be caused by the friction between purposes of their campaign media. On the one hand, candidates want to depict themselves supporting the Covid-19 safety protocols. On the other hand, campaign media also must play their role to establish public awareness toward the candidate so that the public can quickly identify them. Hence, sometimes they depicted themselves wearing a mask improperly so that the audience could recognize their face.

Similarly, breaking social distancing protocols could be caused by the friction between candidates who wanted to depict themselves as supporters of social distancing protocols and the need to depict themselves as open and friendly people, 
enhancing their perceived public image. Lastly, the study also found that the depiction of Covid-19 related imageries in Indonesia local election 2020 was portrayed in a more positive approach than other media outlets such as news coverage. Upon reading on the material, the study did not find any Covid-19 related imageries that depicted the grim and devastating implication of pandemic situation in election campaign media, unlike the imageries that can be frequently seen in news coverages. Considering that something is communicated could affect the audience's perception of the communicator, depicting the Covid-19 pandemic more positively and encouragingly will establish a more positive public image than depicting the Covid-19 pandemic as a hopeless and grim situation.

\section{CONCLUSION}

On the surface level, we could see Covid-19 related imageries in Indonesia local election 2020 campaign media utilized to perform advertising informative function that inform the public on many aspects of the Covid-19 pandemic situation. Advising the public to implement Covid-19 safety protocols, promoting a healthier lifestyle, caring and supporting each other, and especially those who play a pivotal role during the pandemic becomes a piece of encouraging information and reminders for the public on how to deal with the pandemic situation. Along with it, considering the persuasive function of political advertising, the Covid-19 pandemic is utilized by candidates through their election campaign media as a context where each candidate exhibits their value, personality, and capability to enhance his/her personal brand as an attempt to influence voters' decision making. Covid-19 pandemic became one of many contexts in election campaign media utilized by candidates to persuade the voter to lend his/ her vote to him/her.

\section{REFERENCES}

Braun, V., \& Clarke, V. (2006). Using thematic analysis in psychology. Qualitative Research in Psychology, 3(2), 77-101. https://doi.org/10.1191/1478088706qp063oa

Caprara, G. V., Schwartz, S., Capanna, C., Vecchione, M., \& Barbaranelli. (2006). Personality and Politics: Values, Traits, and Personal Choice. Political Psychology, 27(Februari 2006), 1-28. https://doi.org/10.1111/j.1467-9221.2006.00447.x

Caprara, G. V., \& Vecchione, M. (2017). Personalizing Politics and Realizing Democracy. Oxford University Press.

Deighton-Smith, N., \& Bell, B. T. (2018). Objectifying Fitness: A content and thematic analysis of \#Fitspiration images on social media. Psychology of Popular Media Culture, 7(4), 467-483.

https://doi.org/10.1037/ppm0000143 
Dewi, Y. K., \& Probandari, A. (2021). Covid-19 risk factors and health protocol compliance among mall employees and officers in Yogyakarta. Berita Kedokteran Masyarakat, 37(1), 21. https://doi.org/10.22146/bkm.59065

Emamalizadeh, H. (1985). The Informative and Persuasive Functions of Advertising: A Moral Appraisal: A Comment. In Source: Journal of Business Ethics (Vol. 4, Issue 2).

Fahmy, S., Bock, M. A., \& Wanta, W. (2014). Visual Communication Theory and Research: A Mass Communication Perspective. Palgrave Macmillan.

Grabe, M. E., \& Bucy, E. P. (2011). Image Bite Analysis of Political Visuals: Understanding the Visual Framing Process in Election News. In E. P. Bucy \& R. L. Holbert (Eds.), The Sourcebook for Political Communication Research: Methods, Measures, and Analytical Techniques (pp. 209-237). Routledge.

Lotfi, M., Hamblin, M. R., \& Rezaei, N. (2020). COVID-19: Transmission, prevention, and potential therapeutic opportunities. In Clinica Chimica Acta (Vol. 508, pp. 254-266). Elsevier B.V. https://doi.org/10.1016/j.cca.2020.05.044

Lowe-Calverley, E., \& Grieve, R. (2018). Thumbs up: A thematic analysis of image-based posting and liking behaviour on social media. Telematics and Informatics, 35(7), 1900-1913. https://doi.org/10.1016/j.tele.2018.06.003

Montoya, P., \& Vandehey, T. (2009). The Brand Called You: Create a Personal Brand That Wins Attention and Grows Your Business. McGraw-Hill.

Nagel, F., Maurer, M., \& Reinemann, C. (2012). Is There a Visual Dominance in Political Communication? How Verbal, Visual, and Vocal Communication Shape Viewers' Impressions of Political Candidates. Journal of Communication, 62(5), 833-850. https://doi.org/10.1111/j.1460-2466.2012.01670.x

O'Keefe, D. J. (2016). Persuasion: Theory and Research (Third). SAGE Publications.

Perloff, R. M. (2017). Dynamics of Persuasion: Communication and Attitudes in the 21st Century (Sixth). Routledge.

Pratomo, H. (2020). From social distancing to physical distancing: A challenge forevaluating public health intervention against covid-19. Kesmas, 15(2), 60-63. https://doi.org/10.21109/KESMAS.V15I2.4010

Rampersad, H. K. (2008). Authentic Personal Brand: A New Blueprint for Building and Aligning a Powerful Leadership Brand. PPM Publishing.

Russmann, U., Svensson, J., \& Larsson, A. O. (2019). Political Parties and Their Pictures: Visual Communication on Instagram in Swedish and Norwegian Election Campaigns. In A. Veneti, D. Jackson, \& D. G. Lilleker (Eds.), Visual Political Communication (pp. 119-144). Palgrave Macmillan. 
Santilli, P. C. (1983). The Informative and Persuasive Functions of Advertising: A Moral Appraisal. In Source: Journal of Business Ethics (Vol. 2, Issue 1).

Shereen, M. A., Khan, S., Kazmi, A., Bashir, N., \& Siddique, R. (2020). COVID-19 infection: Origin, transmission, and characteristics of human coronaviruses. In Journal of Advanced Research (Vol. 24, pp. 91-98). Elsevier B.V. https://doi.org/10.1016/j.jare.2020.03.005

Coronavirus disease (COVID-19): Risks and safety for older people. (2020, May 8). World Health Organization (WHO).

https://www.who.int/news-room/q-a-detail/coronavirus-diseasecovid-19-risks-and-safety-for-older-people 